\title{
Study of the solidification of M2 high speed steel Laser Cladding coatings ${ }^{(\cdot)}$
}

\author{
J.J. Candel*, P. Franconetti* and V. Amigo*
}

\begin{abstract}
High speed steel laser cladding coatings are complex because cracks appear and the hardness is lower than expected. In this paper AISI M2 tool steel coatings on medium carbon AISI 1045 steel substrate have been manufactured and after Laser Cladding (LC) processing it has been applied a tempering heat treatment to reduce the amount of retained austenite and to precipitate secondary carbides. The study of metallurgical transformations by Scanning Electron Microscopy (SEM) and Electron Back Scattered Diffraction (EBSD) shows that the microstructure is extremely fine and complex, with eutectic transformations and $\mathrm{MC}, \mathrm{M}_{2} \mathrm{C}$ and $\mathrm{M}_{6} \mathrm{C}$ precipitation. Therefore, after the laser coating is necessary to use post-weld heat treatments.
\end{abstract}

\section{Estudio de la solidificación de recubrimientos de acero rápido M2 obtenidos por Laser Cladding}

\begin{abstract}
Resumen
Los recubrimientos de acero rápido por Laser Cladding (LC) son complejos porque aparecen fisuras y la dureza es menor a la esperada. En este trabajo se han fabricado recubrimientos de acero AISI M2 sobre acero al carbono AISI 1045 y tras el procesado por láser, se han revenido para reducir la cantidad de austenita retenida y precipitar carburos secundarios. El estudio de las transformaciones metalúrgicas con Microscopía Electrónica de Barrido (MEB) y Difracción de Electrones Retrodispersados (EBSD) muestra que la microestructura es extremadamente fina y compleja, presenta transformaciones eutécticas y precipitación de carburos $\mathrm{MC}, \mathrm{M}_{2} \mathrm{C}$ y $\mathrm{M}_{6} \mathrm{C}$. Por tanto, tras el recubrimiento por láser es necesario recurrir a tratamientos térmicos post-soldeo.
\end{abstract}

Palabras clave

\section{INTRODUCTION}

High Speed Steels (HSS) exhibit very high wear resistance combined with mechanical strength when proper heat treatment is applied. Thus, they are very appreciated for cutting tool applications ${ }^{[1]}$. Its microstructure is very complex and it is composed by a martensite matrix with $\mathrm{MC}, \mathrm{M}_{2} \mathrm{C}$ and $\mathrm{M}_{6} \mathrm{C}$ secondary carbides embedded ${ }^{[2]}$.

The solidification sequence of AISI M2 high speed steel after ingot casting can be described by the following reactions:

(i) Primary crystallization of $\delta$ ferrite.

(ii) Peritectic reaction: ferrite + liquid $\rightarrow$ austenite.

(iii) Eutectic decomposition of residual interdendritic liquid: liquid $\rightarrow$ austenite + carbides.

Residual ferrite in the dendritic cores transforms to austenite and carbide, which is known as the ' $\delta$ eutectoid transformation'.

Thus, the resulting as cast microstructure has a matrix with products from austenite decomposition (normally martensite and some retained austenite) and a network of eutectic carbides heterogeneously distributed in interdendritic regions ${ }^{[3]}$.

During the decomposition of the residual interdendritic liquid different eutectics can form namely $\gamma-\mathrm{M}_{2} \mathrm{C}, \gamma-\mathrm{M}_{6} \mathrm{C}$, and $\gamma-\mathrm{MC}$. The alloy composition and the cooling rate determine which of these eutectics precipitate. Higher cooling rates and higher vanadium contents favor the formation of $\mathrm{M}_{2} \mathrm{C}$ and $\mathrm{MC}$ eutectics, while higher carbon contents also favor the formation of the $\mathrm{M}_{2}$ C eutectic; the opposite is valid for the $\mathrm{M}_{6} \mathrm{C}$ eutectic. Thus, carbide composition depends on thermomechanical processing and vanadium content ${ }^{[4]}$.

(•) Trabajo recibido el día 17 de octubre de 2012 y aceptado en su forma final el día 8 de julio de 2013.

* ITM, Universitat Politècnica de Valencia, Camino de Vera s/n, 46022 Valencia. E-mail: juacanbo@upv.es 
However, laser processing of AISI M2 coatings imposes a fast localized heating till melting followed by very fast cooling due focused laser irradiance applied. Therefore an abrupt thermal gradient combined with a very high solidification rate is formed inside melting pool which promotes metastable phases formation and coating cracking ${ }^{[5]}$. To overcome these difficulties it is necessary to study the solidification of AISI M2 tool steel coating relating the microstructure to the laser processing window.

HSS microstructure determination after LC is very complex because of extremely fine grain size (less than $5 \mu \mathrm{m}$ ) and phase distribution. On one hand, lattice parameters of $\mathrm{MC}$ or $\mathrm{M}_{2} \mathrm{C}$ carbides can be different depending on molybdenum, tungsten content (Table I). And on the other hand, crystallography of the present phase is not completely established as in the case of $\mathrm{VC}\left(\mathrm{VC}, \mathrm{V}_{8} \mathrm{C}_{7}\right.$ or $\mathrm{V}_{6} \mathrm{C}_{5}$ can be present $)^{[6]}$. This problem is more acute in the case of LC coating due to microstructure heterogeneity imposed by cooling rate.

Hertzner et al., remark the importance of combining Scanning Electron Microscopy (SEM) and Electron Back Scattered Diffraction (EBSD) to determine the composition and phase distribution in the microstructure after high alloying steels heat treating ${ }^{[7]}$. And for this reason, in this work this approach has been used and it has been completed with nanoindentation measurements to quantify the effect of the microstructure on the strength of the coating.

\section{EXPERIMENTAL METHOD}

\subsection{Laser system and raw materials}

Continuous wave Nd:YAG laser system equipped with coaxial cladding laser head was used for manufacturing coatings. After process optimization, it has been fixed $\mathrm{E}=21 \mathrm{~J} / \mathrm{mm}^{2}$ as an optimum laser specific energy $(\mathrm{P}=400 \mathrm{~W}, \mathrm{~V}=9.5 \mathrm{~mm} / \mathrm{s})$ and 20 single overlapped tracks have been deposited to form the coating.

A $5 \mathrm{~mm}$ height AISI 1045 carbon steel plate has been used as a substrate and before laser processing, surface was grinded using a P500 SiC paper and degreased with acetone.

Argon atomized AISI M2 (EN 1.3344) HSS steel powder was used as a coating. This spherical powder has a specific granulometry for LC $(+30 \mu \mathrm{m},-75 \mu \mathrm{m})$ and its chemical composition is $1.22 \% \mathrm{C}, 4.1 \% \mathrm{Cr}$, 5\% Mo, 2.9\% V, 6.4\% W, Fe bal.

After laser processing one coating was subjected to tempering heat treatment at $550^{\circ} \mathrm{C}$ during $2 \mathrm{~h}$. The objectives are to enhance secondary carbide precipitation as well as to reduce the amount of retained austenite.

\subsection{Materials characterization}

Coating cross section after and before tempering heat treatment has been metallographically prepared for observation and the microstructure was revealed with Vilella etchant (95 ml Etanol, $5 \mathrm{ml} \mathrm{HCl}, 1 \mathrm{~g}$ Picric acid).

Two different areas were selected for optical microscopy characterization, the interface between coating and substrate and the center of the coating (Fig. 1). The microstructure was observed with SEM and the chemical composition determined by Energy Dispersive Spectroscopy (EDS). Finally, the phase maps distribution and orientation was determined with Electron Back Scattered Diffraction (EBSD). EBSD analysis of laser cladding HSS coatings is very complex and time consuming due to the extremely fine grain size and the great variety of present phases,

Table I. Type, structure and lattice parameters of some carbides present in AISI M2 steel LC coatings

Tabla I. Tipo, estructura y parámetros de red de algunos carburos presentes en los recubrimientos de acero AISI M2 obtenidos por láser cladding

\begin{tabular}{lllcl}
\hline Phase & Structure & a & c & Type \\
\hline WC & Hexagonal & 0.29006 & 0.2837 & $\mathrm{MC}$ \\
$\mathrm{W}_{2} \mathrm{C}$ & Hexagonal & 0.2997 & 0.4727 & $\mathrm{M}_{2} \mathrm{C}$ \\
$\mathrm{MoC}$ & Hexagonal & 0.2901 & 0.2786 & $\mathrm{MC}$ \\
$\mathrm{Mo}_{2} \mathrm{C}$ & Hexagonal & 0.3012 & 0.4735 & $\mathrm{M}_{2} \mathrm{C}$ \\
$\mathrm{W}_{3} \mathrm{Fe}_{3} \mathrm{C}$ & FCC & 1.1109 & & $\mathrm{M}_{6} \mathrm{C}$ \\
\hline
\end{tabular}



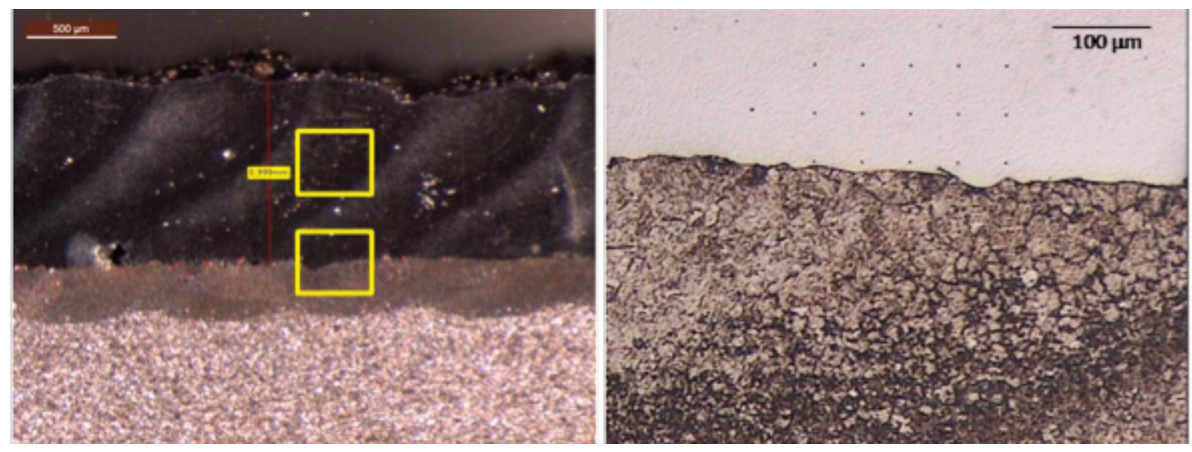

Figure 1. Cross section of the coating and selected areas for analysis.

Figura 1. Sección transversal del recubrimiento y áreas seleccionadas para el análisis.

but coating delamination through interface justifies focusing EBSD analysis in this area.

In this preliminary work, different type phases have been selected ( $\mathrm{MC}, \mathrm{M}_{2} \mathrm{C}, \mathrm{M}_{6} \mathrm{C}$ ) taking into account that X-Ray Diffraction analysis should be necessary to determine if $\mathrm{M}$ is tungsten, molybdenum or vanadium with accuracy (Table II). For metal matrix analysis, martensite and austenite have been selected as candidates. For secondary carbides determination, it has been selected $\mathrm{M}=\mathrm{W}$ in $\mathrm{MC}$, $\mathrm{M}_{2} \mathrm{C}$ and $\mathrm{M}_{6} \mathrm{C}$ phases, taking into account that tungsten could be substituted by molybdenum, iron or vanadium with small lattice variations. There have not been included vanadium carbides due to their great variety, complexity $\left(\mathrm{VC}, \mathrm{V}_{6} \mathrm{C}_{5}, \mathrm{~V}_{7} \mathrm{C}_{8}, \mathrm{~V}_{2} \mathrm{C}\right)$ and residual contribution to mechanical properties.

Materials characterization is completed with nanoindentation analysis in order to determine the influence of phase distribution on nanohardness. Nanoindentation was done using Berkovich indenter and Oliver \& Pahrr method. An array of $5 \times 5$ indents was done in the interface and in the center of the coating with $\mathrm{F}=50 \mathrm{mN}$ and $50 \mu \mathrm{m}$ separation between indents.

\section{RESULTS AND DISCUSSION}

\subsection{Coating microstructure before heat treatment}

Coating microstructure is mainly composed by a cellular microstructure of approximately $5 \mu \mathrm{m}$ mean equivalent grain diameter. It is an ultrafine martensitic microstructure with secondary carbides dispersion mainly accumulated at border grains (Fig. 2 A)). Near the interface between the coating and the substrate, due to very high cooling rate, the dendritic microstructure is present and border grain carbide precipitation is more evident (Fig. 2 B)).

At higher magnification a eutectic transformation in border grain can be appreciated (Fig. 2 B)). According with Boccalini M2 eutectic transformation during solidification can be $\gamma-\mathrm{M}_{2} \mathrm{C}, \gamma-\mathrm{M}_{6} \mathrm{C}$ or $-\mathrm{MC}$ depending on cooling rate, composition and maximum temperature ${ }^{[3]}$.

EDS microanalysis confirm that chemical composition of coating center area (EDS 1 ) is close to M2 powder initial composition (Table III).

Table II. Selected phases for EBSD analysis

Tabla II. Fases seleccionadas para el análisis por EBSD

\begin{tabular}{ccc}
\hline Phase group & Selected phase & Crystallography \\
\hline Iron phase & Martensite & Tetragonal \\
Iron phase & Austenite & Face centered cubic \\
$M C$ & $W C$ & Hexagonal close packed \\
$M_{2} C$ & $W_{2} C 7$ & Hexagonal primitive \\
$M_{6} C$ & $\mathrm{Fe}_{3} W_{3} \mathrm{C}$ & Face centered cubic \\
\hline
\end{tabular}



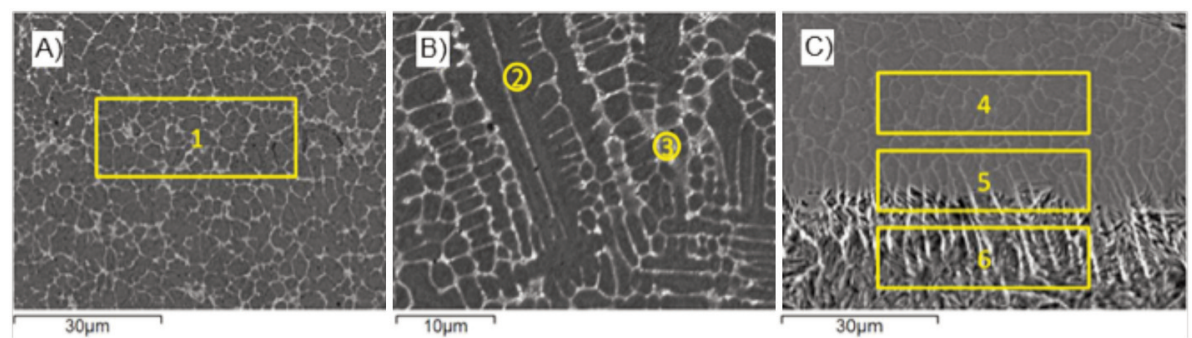

Figure 2. Microstructure of the coating before tempering: A) Center zone; B) Dendritic zone; C) Coating-substrate interface.

Figura 2. Microestructura del recubrimiento antes del revenido: A) Zona central; B) Zona dendrítica; C) Intercara recubrimiento-substrato.

However, small variations are observed in dendritic zone due to diffusion between coating and substrate (EDS 2 and 3). Dendritic core is iron, W-rich and according with Serna et al. ${ }^{[4]}$, it could be a martensite $-\mathrm{M}_{6} \mathrm{C}$ zone whereas interdendritic region where eutectic transformation is present is rich in alloying elements as carbon, molybdenum and vanadium. Interface EDS analysis (EDS 4, 5 and 6 in Fig. 2 C)) remarks carbon diffusion to substrate whereas other sluggish alloying elements diffusivity like tungsten or molydenum is reduced. That is why zones 5 and 6 are very hard and fragile compared to AISI 1045 standard mechanical properties.

\subsection{Coating microstructure after heat treatment}

After tempering heat treatment it has been observed important chemical compositional change in coating and sub-interface HAZ. In cellular and dendritic microstructures, alloying element content is reduced inside cells (EDS 7 in Fig. 3 A)) whereas it augments in border grain due to secondary carbide precipitation (EDS 8 in Fig. 3 A)), as could be expected. However, another beneficial effect has been observed inside HAZ, alloying element content augments due to diffusion and secondary carbides also precipitate in HAZ. Thus, previous hard and fragile martensite is replaced by another complex microstructure formed by tempered martensite and secondary carbides.

\subsection{EBSD analysis of phase transformations}

Backscattered electron image of interface zone shows an abrupt transition before heat treatment (Fig. 4 A)). Heat affected zone (HAZ) is primary

Table III. EDS microanalysis results from figures 2 and 3

Tabla III. Resultados del microanálisis por EDS de las figuras 2 y 3

\begin{tabular}{cccccccc}
\hline Zone & C & V & Cr & Mn & Fe & Mo & W \\
\hline 1 & 1.97 & 2.45 & 3.71 & 0.36 & 80.52 & 4.5 & 6.49 \\
2 & 2.22 & 1.62 & 3.35 & 0.32 & 85.25 & 2.63 & 4.63 \\
3 & 5.08 & 4.51 & 4.28 & 0.39 & 69.42 & 6.75 & 3.58 \\
4 & 4.12 & 2.68 & 3.42 & 0.44 & 80.18 & 5.08 & 6.31 \\
5 & 2.07 & 2.17 & 2.82 & 0.46 & 83.41 & 3.87 & 5.21 \\
6 & 1.95 & 0.35 & 0.51 & 0.54 & 92.99 & 0.63 & 0.86 \\
7 & 2.31 & 1.5 & 2.85 & 0.33 & 85.07 & 2.64 & 5.3 \\
8 & 3.87 & 5.64 & 4.45 & 0.45 & 65.48 & 9.36 & 10.75 \\
9 & 1.78 & 2.67 & 3.77 & 0.48 & 80.08 & 4.37 & 6.84 \\
10 & 1.6 & 2.52 & 3.74 & 0.35 & 80.93 & 4.57 & 6.29 \\
11 & 3.07 & 1.19 & 1.90 & 0.61 & 87.61 & 2.28 & 3.34 \\
\hline
\end{tabular}



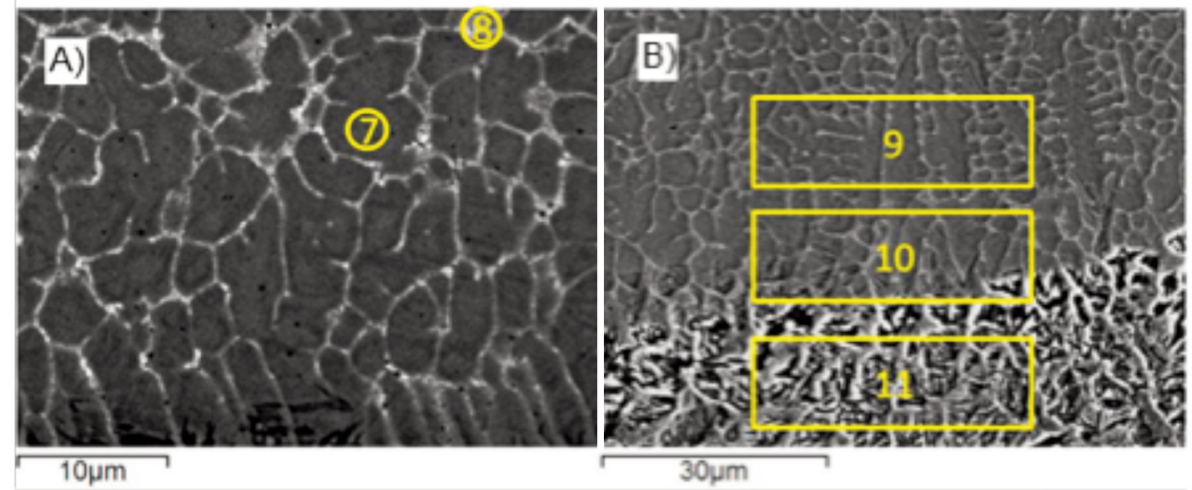

Figure 3. Microstructure of the coating after tempering: A) Cellular zone;

B) Coating-substrate interface.

Figure 3. Microestructura del recubrimiento después del revenido: A) Zona celular; B) Intercara recubrimiento-substrato.

composed by martensite transformed inside austenite previous grain and for this reason EBSD quality pattern is excellent (Fig. 4 B)). Inside dendritic zone pattern quality is reduced due to microstructure complexity, thermal stress and extremely fine carbide and porosity dispersion. However, it can be appreciated that dendrite cores are basically martensite whereas interdendritic region is composed by austenite and carbides formed after eutectic decomposition of residual liquid (Fig. 4 C)). According with Boccalini $\gamma-\mathrm{M}_{2} \mathrm{C}, \gamma-\mathrm{M}_{6} \mathrm{C}$ or $\gamma$-MC should be the main phases distribution but it is formation depends on cooling rate and $\mathrm{V}$-content during casting. With $2 \%$ vanadium and very low cooling rates $(1.5 \mathrm{~K} / \mathrm{s})$ a duplex $\mathrm{MC} / \mathrm{M}_{2} \mathrm{C}$ microstructure was expected ${ }^{[3]}$. But, during LC process the significance of this information is restricted because of cooling rates higher than $10^{3} \mathrm{~K} / \mathrm{s}$ and microstructure segregation that promote martensite transformation.

After tempering (Fig. 4 D), E) and F)), martensite revenue and secondary carbide precipitation takes place, dendritic microstructure is eliminated and a more gradual transition coatingsubstrate interface is observed. Although $\mathrm{MC}, \mathrm{M}_{2} \mathrm{C}$ and $\mathrm{M}_{6} \mathrm{C}$ content (with $\mathrm{M}=\mathrm{W}, \mathrm{Mo}$ ) augments another secondary carbides with major $\mathrm{V}$-content precipitates and for this reason non-identified

Table IV. Nanohardness measurements

Tabla IV. Medidas de nanodureza

\begin{tabular}{lcccccr}
\hline & \multicolumn{2}{c}{ Rec 1 } & Rec 1 Tempered & \\
\hline & Row & Havg & Hsig & Havg & Hsig & $\begin{array}{r}\text { Dis tinter } \\
(\mathbf{m m})\end{array}$ \\
\hline Center & 1 & 9.576 & 0.651 & 11.946 & 0.54 & 500 \\
& 2 & 9.484 & 0.322 & 12.132 & 0.259 & 450 \\
& 3 & 9.522 & 0.545 & 11.556 & 0.492 & 400 \\
& 4 & 9.590 & 0.606 & 11.992 & 0.199 & 350 \\
Interface & 5 & 9.902 & 0.744 & 11.850 & 0.358 & 300 \\
& 1 & 9.596 & 0.463 & 12.080 & 0.316 & 100 \\
& 2 & 9.190 & 0.352 & 11.782 & 0.304 & 50 \\
& 3 & 5.105 & 0.168 & 6.402 & 0.128 & 0 \\
& 4 & 4.932 & 0.144 & 5.856 & 0.035 & -50 \\
& 5 & 4.638 & 0.309 & 5.604 & 0.254 & -100 \\
\hline
\end{tabular}



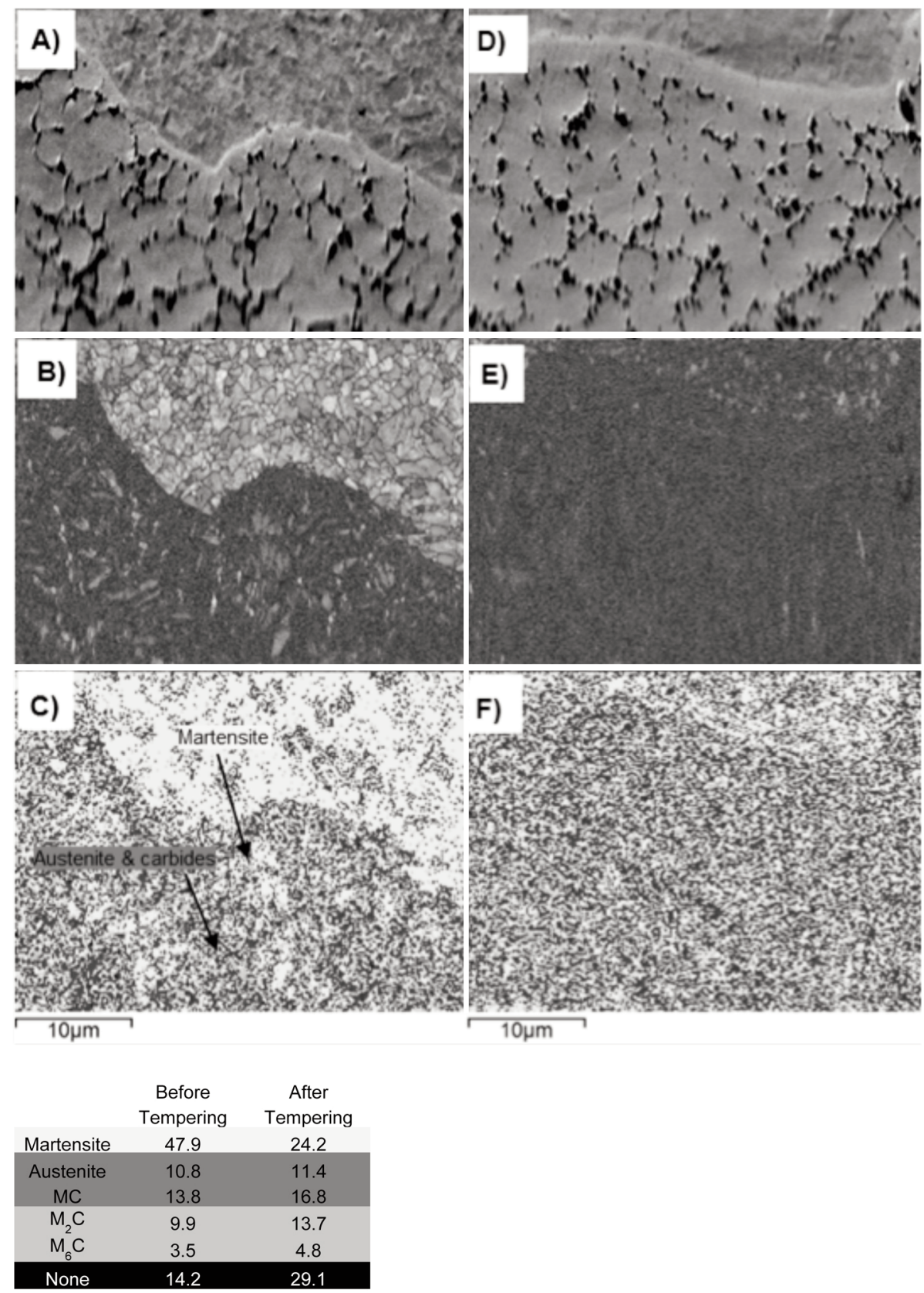

Figure 4. EBSD phase maps: $S E I$ image of EBSD area (A and $D)$; Quality patterns ( $B$ and $E$ ); Phase distribution map ( $C$ and $F$ ).

Figura 4. Mapas de fase por EBSD: imagen SEl de área EBSD ( $A$ y $D$ ); Patrones de calidad ( $B$ y E); Mapa de distribución de fases (C y F).

phases content augments too. However, contrary than expected, retained austenite content is not reduced. Author's hypothesis is laser processing of HSS steels retains an appreciable amount of $\delta$-ferrite, after tempering $\delta$-ferrite is transformed to austenite, and for this reason austenite content increases. During conventional HSS steels solidification, the peritectic reaction forms austenite from liquid plus $\delta$-ferrite, therefore a very high cooling rate could suppress this transformation and a residual amount of $\delta$-ferrite could be retained at room temperature. This phenomenon will be deeply investigated in future works using TEM microscopy in order to contrast the hypothesis.

Pole figure analysis of the present phases before heat treatment indicates that there is no significant texture for martensite (Fig. 5 C)). The eutectic transformation to form carbides (mainly $\mathrm{MC}, \mathrm{M}_{2} \mathrm{C}$ ) 


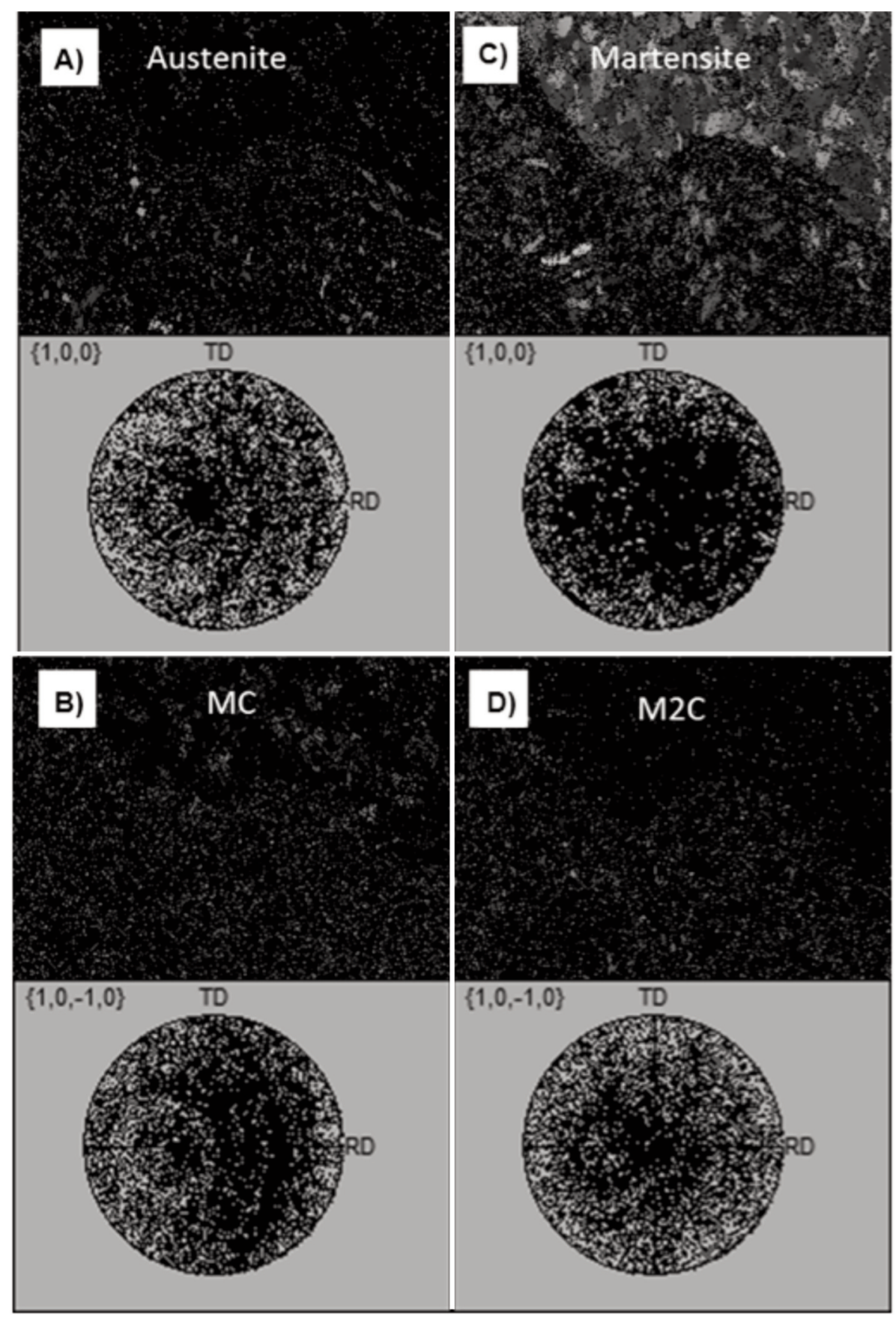

Figure 5. Pole figures of the present phases before tempering.

Figura 5. Figuras de polos de las fases presentes antes del revenido.

and austenite causes a particular solidification texture which depends on laser processing parameters and it is observed in pole figures with a circular pattern (Fig. 5 A), 5 B) and 5 D)).

After tempering, this solidification texture is more evident and clear (Fig. 6). All the present phases follow the same circular pattern due to metastable phase reduction and thermal stress relieving.

\subsection{Nanoindentation analysis of coatings}

For every distance to the interface, a complete row of nanoindentation matrix, the average and standard deviation have been calculated to examine nanohardness evolution (Table IV). Nanohardness measurements in the center of the coating (cellular zone) and in the interface (dendritic zone) depict the 

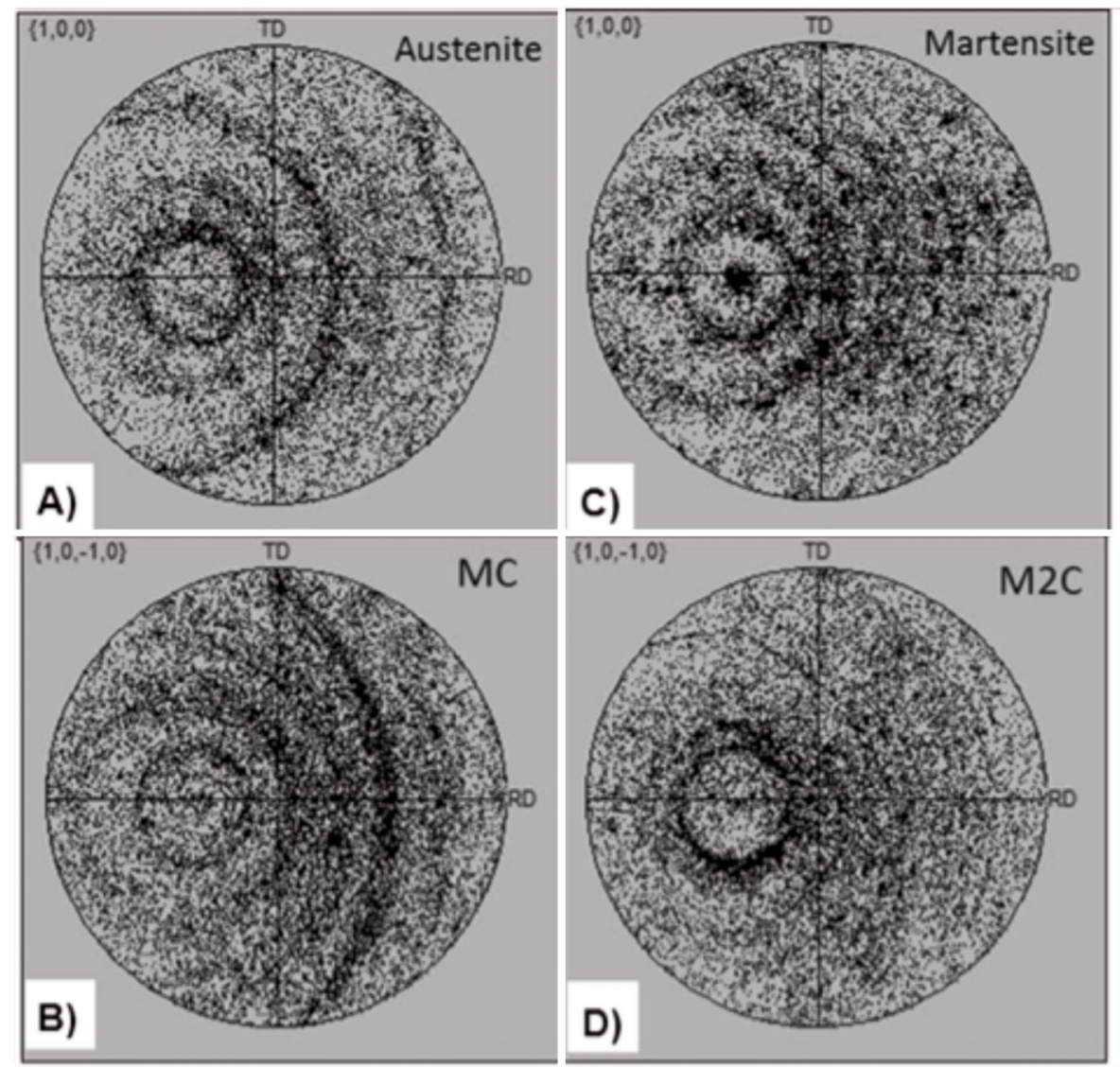

Figure 6. Pole figures of the present phases after tempering.

Figura 6. Figuras de polos de las fases presentes después del revenido.

homogeneity in the coating and remark the abrupt transition of hardness between coating and substrate after laser processing. No significant difference between lower dendritic and upper cellular zone hardness has been observed and its average value is about $9.6 \mathrm{GPa}$ which is enough for final application of the coating.

After tempering, the average nanohardness increases above the expected level to arrive at $11.9 \mathrm{GPa}$ due to the extremely fine microstructure comparing to cast HSS ${ }^{[8]}$ (Table IV). However it is in the interface zone where the most beneficial effect takes place. As expected in EBSD analysis, the HAZ close to the interface augments its nanohardness although it is composed by tempered martensite due to secondary carbide precipitation inside. Thus, thermal stress is relieved and microstructures have changed to another tougher than previous martensite without hardness loss.

\section{CONCLUSIONS}

The laser processing increases the complexity of the structure AISI M2 high speed steel, due to the formation of metastable phases and ultra-fine grain structure. Using the combined approach based on electron microscopy, EBSD and Nanoindentation is possible to identify phases at local level.

- The phase identification using EBSD is very complex, not only because of the similarity between different hexagonal phases $\left(\mathrm{WC}, \mathrm{W}_{2} \mathrm{C}\right.$, $\mathrm{MoC}, \mathrm{Mo}_{2} \mathrm{C}$ ) but also to the vanadium solution effect.

- Ultrafine martensitic cellular structures are formed with grain boundary eutectic of austenite plus $\mathrm{MC} / \mathrm{M}_{2} \mathrm{C}$ carbides. In addition, carbon diffusion to the sub-interfacial HAZ provokes cracks after LC due to thermal stress.

- Dendritic microstructure is eliminated and other complex carbides precipitate enhancing the interfacial mechanical properties after tempering.

- A significant amount of $\mathrm{MC} / \mathrm{M}_{2} \mathrm{C}$ ultrafine hexagonal carbides $(\mathrm{M}=\mathrm{W}, \mathrm{Mo})$ and retained austenite is still present and the final microstructure is different from the cast M2 tool steel.

- It is important to continue the research into the identification of phases present by $\mathrm{X}$-ray 
diffraction in order to confirm the presence of predefined phases and to introduce new ones to improve the identification by EBSD.

\section{REFERENCES}

[1] G. Robert, G. Krauss and R. Kennedy, Tool steels, $5^{\text {th }}$ Edition, Materials Park, ASM International, EE.UU., 1998.

[2] R. Mesquita and A. Barbosa, Mat. Sci. Eng. A 383 (2004) 87-95.
[3] M. Boccalini, A.V.O. Correa, and H. Goldenstein, Mater. Sci. Techn. 15 (1999) 621.

[4] M. Serna and J. Rossi, Mater. Lett. 63 (2009) 691-693.

[5] K.Y. Benyounis, O.M. Fakron and J.H. Abboud, Mater. Design. 30 (2009) 674-678.

[6] M. Godec, B. Bati and D. Mandrino, Mater. Charact. 61 (2010) 452-458.

[7] D.W. Hetzner and W. Van Geertruyden, Mater. Charact. 59 (2008) 825-841.

[8] M. Riabkina, E. Rabkin and P. Levin, Mat. Sci. Eng. A 302 (2001) 106-114. 